\title{
The Sábana de Santa Eufemia from the Cathedral of Ourense. A healing tissue ${ }^{1}$ La Sábana Santa de Santa Eufemia de la
catedral de Ourense. Un tejido sanador
}

ASUNCIÓN LAVESA MARTín-SERRANO

Calle Tenerife 11. 28039 Madrid

asun.lavesa@gmail.com

\begin{abstract}
This paper is a report of the first archaeological research ever carried out on the so-called "Sábana de Santa Eufemia". It is a very well-preserved embroidery in white from the reliquary of Saint Euphemia in the Cathedral of Ourense (Galicia, Spain), which is currently kept in the Cathedral Museum. The textile shows a very lavish decoration formed by an array of motifs taken from different cultural traditions. This point leads to think it was made in post-medieval times by someone who was familiar with medieval cloths of honour which were probably part of the Cathedral Treasury.
\end{abstract}

Key words: textile, embroidery, relics, medieval, Renaissance, Ourense Cathedral

\section{Resumen}

Avance de los resultados del estudio arqueológico que se está llevando a cabo sobre la llamada «Sábana de Santa Eufemia», el primero que se efectúa en la historia de la pieza. Es un bordado en blanco procedente del relicario de Santa Eufemia de la Catedral de Ourense (Galicia, España), que se puede admirar en el Museo Catedralicio, y que está en excelentes condiciones de conservación. El tejido presenta una decoración muy profusa formada por un conjunto de motivos tomados de diferentes tradiciones culturales, lo que indicaría que fue confeccionado en época post-medieval por alguien que había visto algún paño de honor que sí era medieval, y que probablemente formaba parte del Tesoro de la misma catedral.

Palabras clave: tejido, bordado, reliquias, medieval, renacentista, Catedral de Ourense

1 This paper would have never existed if not for the priceless support and help from Mister Miguel Ángel González, Canon Archivist of the Cathedral of Ourense, who kindly provided me all the support for the analysis of this item. I would also like to thank Professor Doctor Fernando Valdés for informing me about the existence of this tissue and for connecting me and Mister Miguel Ángel González. 
The so-called Sábana de Santa Eufemia ("Sant Euphemia's Tissue") is notable for its originality amongst the treasures kept in the Museum of the Cathedral of Ourense (Galicia, Spain) (figure I). It is a large vegetal fibre embroidery displaying a very lush and eye-catching decoration. What follows is a report focused on the initial stages of the first ever research carried out on it.

The presence of this embroidery in the reliquary of Saint Euphemia is related to the medieval practice of using rich, imported textiles to enhance or to protect the most sacred relics. These are the so-called "cloths of honour": luxury fabrics, often profusely decorated, and generally full of symbolism alluding power and the afterlife. These items themselves become secondary relics when in touch with the holy bodies, and thus are venerated.

\section{Methodology}

The method I am applying is based on that used in Archaeology. Every reference to the textile in the historical written sources, as well as in the contemporary works, have been studied to provide a historical background to the piece. This initial investigation was followed up by a visual analysis of the cloth. I describe its decoration and its weaving technique (as far as can be completed by the naked eye). I have taken a comprehensive photographical record of the decoration and the base fabric. These pages reflect the results of these first stages of the investigation.

A second part of the research will entail the taking of several samples of threads of the sheet as well as of embroidery for later analysis in a laboratory. This will determine the material and the techniques used for the embroidery. It will also provide an exact dating for the piece. Therefore, this stage is necessary for the completion of the study of the textile.

\section{Saint Euphemia and her relics}

In I727, Juan Muñoz de la Cueva (I660-I728) recounts the life of Saint Euphemia. According to him, she was a martyr who evangelised in the Parish of
Lobios, in the Southern part of the region of Limia (Ourense, Galicia, Spain). The provided dates for the life of the Saint are unclear in so far as her hagiography seems to be a literal calque of that of Saint Euphemia of Chalcedon (289-304). It appears that the Galician Euphemia lived a century earlier than the Oriental one. This Saint Euphemia's cult reached a widespread devotion in the lands of Ourense. The Cathedral's main chapel and two of the historical Parish churches in the city were dedicated to her advocacy.

Saint Euphemia was supposedly born in Balcagia (near nowadays Bayona, Pontevedra, Galicia, Spain) around the year I2O. Muñoz de la Cueva tells that she was one of the nonuplets of Lucius Castelius Severus, governor of Gallaecia and Lusitania. His wife, frightened by giving birth to so many girls at the same time, ${ }^{2}$ instructed her maid to drown them into the river. Instead, she gave them away distributing the babies among Christian families in the area so they would be raised in the maid's own faith. Years later, as part of the persecutions of Christians during Hadrian's administration, all nine of the girls were brought before their father, accused of being Christian. When he learnt they were his daughters, he made them choose between renouncing to their faith, or torture to death. They did not renounce, and so they fled, and each took refuge in a different territory. Euphemia hid in the Xurés Mountains, where she evangelised the population. Seemingly, after a while, she was found and was martyred by being thrown off a cliff after being tortured. Her body was recovered by several of her followers and buried in the outskirts of Obobriga (Terras do Bouro, Minho, Portugal) around the year I40 (Muñoz de la Cueva, I727, Libro IV, caps. I-V: IOI-I24).

Muñoz de la Cueva reports that her tomb was found in rogo (Muñoz de la Cueva, I727, Libro IV, cap. VI: 124, I27). It was a stone sarcophagus placed under the altar in the church of Santa Marina. The legend says that in the place of Campelo, in the Parish

2 Multiple births were considered a clear sign of the wife's infidelity, being compared to swine giving birth many piglets at once. Thus, medieval sources frequently refer to mothers of children being born in such labors trying to get rid of them. 


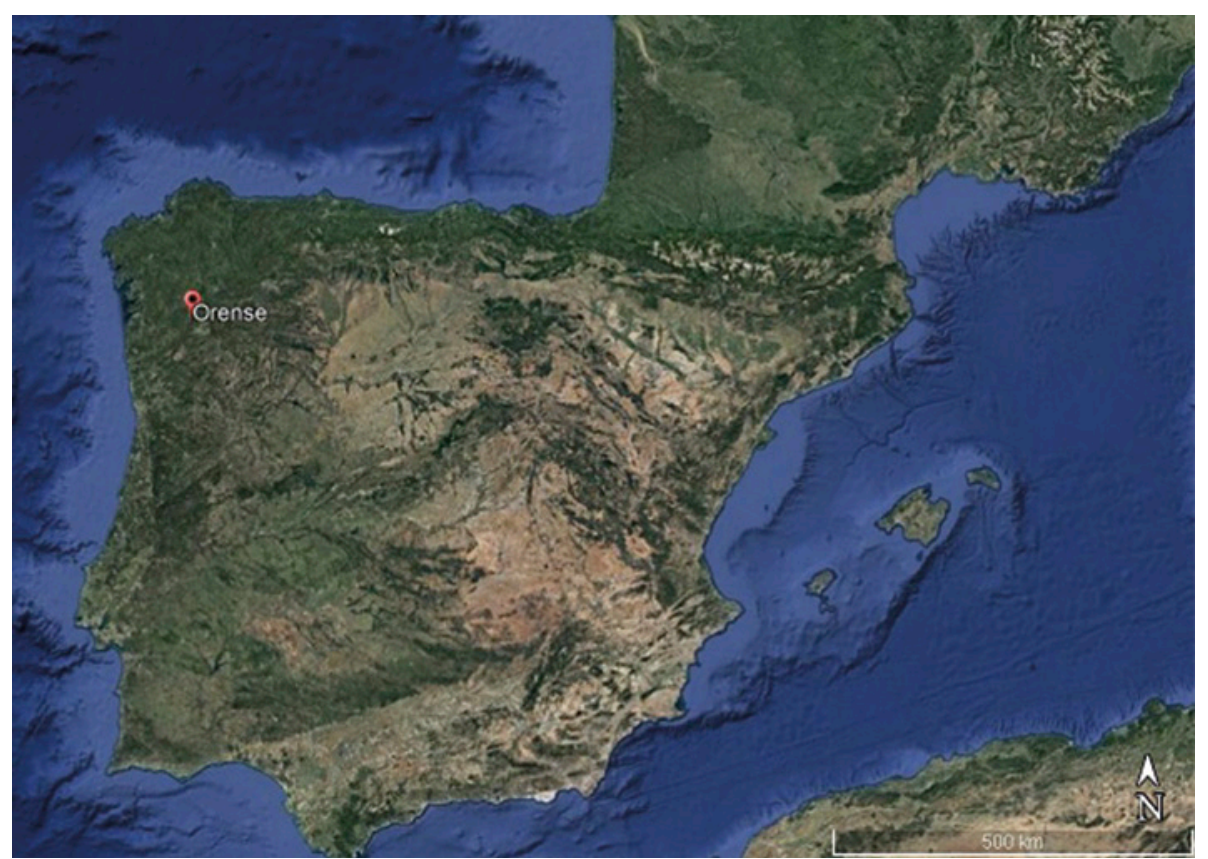

Figure 1. Location of the city of Ourense

Figura 1. Localización de la ciudad de Ourense

of San Salvador de Manín (in Lobios), a little shepherdess saw a hand with a gold ring sticking out of some rocks. She took the ring and instantaneously lost her ability to speak. Once the shepherdess' father found out, he took the girl to that place and made her return the ring. In that same moment a voice was heard in the mountains, saying: "Aquí está el cuerpo de Santa Eufemia, date prisa à pasarlo con la reverencia debida à la Iglesia de Santa Marina" ("Here lies the body of Saint Euphemia, hurry and take it with due reverence to the Church of Santa Marina") (Florez, 1765: 148). Thus, the body was exhumed, and then buried again in the Church of Santa Marina in Lobios. This was an area in constant dispute between the Dioceses of Braga and Ourense. This relocation was another motive for conflict between both Sees. It was eventually resolved by placing the body on a cart pulled by two oxen, and letting providence decide where the animals would stop. It was in the village of Seixalvo, in the parish of Lobios (Ourense), where a chapel was built in honour of Euphemia, which remained standing until the $\mathrm{I}^{6^{\text {th }}}$ century (Muñoz de la Cueva, I727, Libro IV, cap. VII: I30).

The body of Saint Euphemia was kept in that chapel until the $\mathrm{I}^{\text {th }}$ century. The translocation of the remains of the Saint from the chapel to the
Cathedral of Ourense took place either in II59 or II62, under the Bishopric of Pedro Seguín. Once again a confrontation was provoked with the Dioceses of Braga. The Bishop himself had to intervene (Muñoz de la Cueva, I727, Libro IV, cap. VII: I28-I3I). It is most likely that the ascription of the hagiography of Saint Euphemia of Chalcedon happened at this time. It is an attempt to invest the Galician Saint of a stronger, more sacred status, in a similar way to what happened with the relics of Saint James. This is a very frequent form of inventio in the Middle Ages.

\section{The Sábana in the historical sources}

The oldest mentions to the relics of Saint Euphemia are two documents from Ir6o. The first is a donation from Fernando II of León to the Abbot of the Monastery of San Lorenzo de Siabal (Paderne de Allariz, Ourense, Galicia, Spain) in thanks for the intercession of the Saint in the healing of the King from an unspecified ailment. The second document dates to June of the same year, and is the concession of six days of full safety for pilgrims on the date of the relocation of the Saint's body, on July $26^{\text {th }}$, "cuius sanctissimum corpus in auriense ecclesia reciescit" ("whose most holy body rests in 
the church of Ourense") (Rodríguez González, 20I3: I). Neiher of these documents mention the tissue nor any other textile accompanying the relics.

There is silence in the written sources from this moment until the $\mathrm{I}^{\text {th }}$ century. Ambrosio de Morales, in his Viage of 1572, alludes to Saint Euphemia's martyrdom, the discovery of the body, and its translocation to the church of Santa Marina. Likewise, he refers to the ark and the sheet that covered the relics as follows: "[...] Tienen en la Sacristia en un Arca de marfil la Sabana en que estaba envuelto el Santo Cuerpo quando se hizo la postrera elevación. Es toda labrada de buena labor blanca [...]” ("[...] They have at the sacristy in an ivory ark the tissue in which the Holy Body was wrapped when It made the last elevation. It is embroidered in a good white labour [...]") (Florez, I765: 149).

There are two mentions of the tissue in two catalogues of Episcopal visits kept in the Archives of the Cathedral. ${ }^{3}$ The first one is the visit of Fernando Tricio de Arenzana, who was the Bishop between 1565 and 1578 . Apropos of the ivory reliquary called of Saint Susan, it mentions that "[...] Así mismo esta dentro una sábana como manteles con unos lazos labrados con hilo tiene 20 palmos de largo y seis de ancho en la cual hallaron envuelto el cuerpo de la gloriosa virgen Santa Eufemia [...]”'“[...] Likewise, inside there is a sheet like table cloths with some laces embroidered with thread it is 20 palms long and six wide in which the body of the glorious virgin Euphemia was wrapped [...]") (Visita del obispo Fernando Tricio de Arenzana. Archivo de la Catedral de Ourense, $\mathrm{ACO} 73 / 4$ ).

The second reference from this time is the visit of Bishop Juan de Sanclemente in I583. It also mentions the ark of Saint Susan, and it states that "[...] En esta arca está una sábana que dicen ser de Santa Eufemia fue hallada es un monumento y está labrada de filo blanco [...]" ("[...] In this ark there is a tissue said to be Saint Euphemia's. It is a monument

3 Once more I warmly thank Mister Miguel Ángel González, Canon Archivist of the Cathedral, for his generosity in providing me the information about these documents. and it is embroidered in white thread [...]") (Visita del obispo don Juan de Sanclemente de 1583. Archivo de la Catedral de Ourense, $\mathrm{ACO} 73 / \mathrm{r} 2$ ).

These are the oldest recounts of, apparently, Saint Euphemia's textile. It is described as a work embroidered in white with similar dimensions and shape to a tablecloth. The reports make possible to determine a post quem date to the piece.

Remarkably the three descriptions coincide that there is a second tissue kept with the relics of the Saint, said to be the original veil that covered her head. Ambrosio de Morales calls it velo (veil), and describes it as "de toca algo basta, y parece morisca por unas listas que tiene de seda colorada" ("a bit coarse headdress, and it seems Moorish for some lists made in red silk which it has") (Florez, I765: 149).

In the visit of Bishop Fernando Tricio de Arenzana it is mentioned that "[...] asimismo esta dentro en la dicha arca una toca que tiene siete palmos de largo y un medio de ancho que es de la virgen Santa Eufemia que tenía en la cabeza cuando fue hallada. Tiene alrededor por la una parte de Colorado y blanco y al un cabo otras dos orillas colorado y verde." ("[...] furthermore, inside the mentioned ark it is a headdress that is seven palms long and a half wide which is virgin Saint Euphemia's that was on her head when it was found. Around one part is red and white, and at one end other two edges red and green.") (Visita del obispo Fernando Tricio de Arenzana. Archivo de la Catedral de Ourense, $\mathrm{ACO} 73 / 4$ ).

The record of the visit of Bishop Juan de Sanclemente does not cite this headdress or veil. Instead, it mentions some relics that were kept together in the Ark of Saint Susan. Some of them had healing qualities:

[...] Otra caja grande de marfil aforrada en tafetán y con su llave en cuyo contorno hay figuras de bulto de la historia de Santa Susana dentro de esta caja hay una bolsa de cuero dorada y dentro unas reliquias que dicen ser del báculo de San Eleuterio obispo y otras de anciana su madre en las que puso nuestro señor la virtud que son su tacto sanan los que tienen mal de rabia y tres piezas cubiertas con telilla de seda y tres huesos descubiertos [...]. 


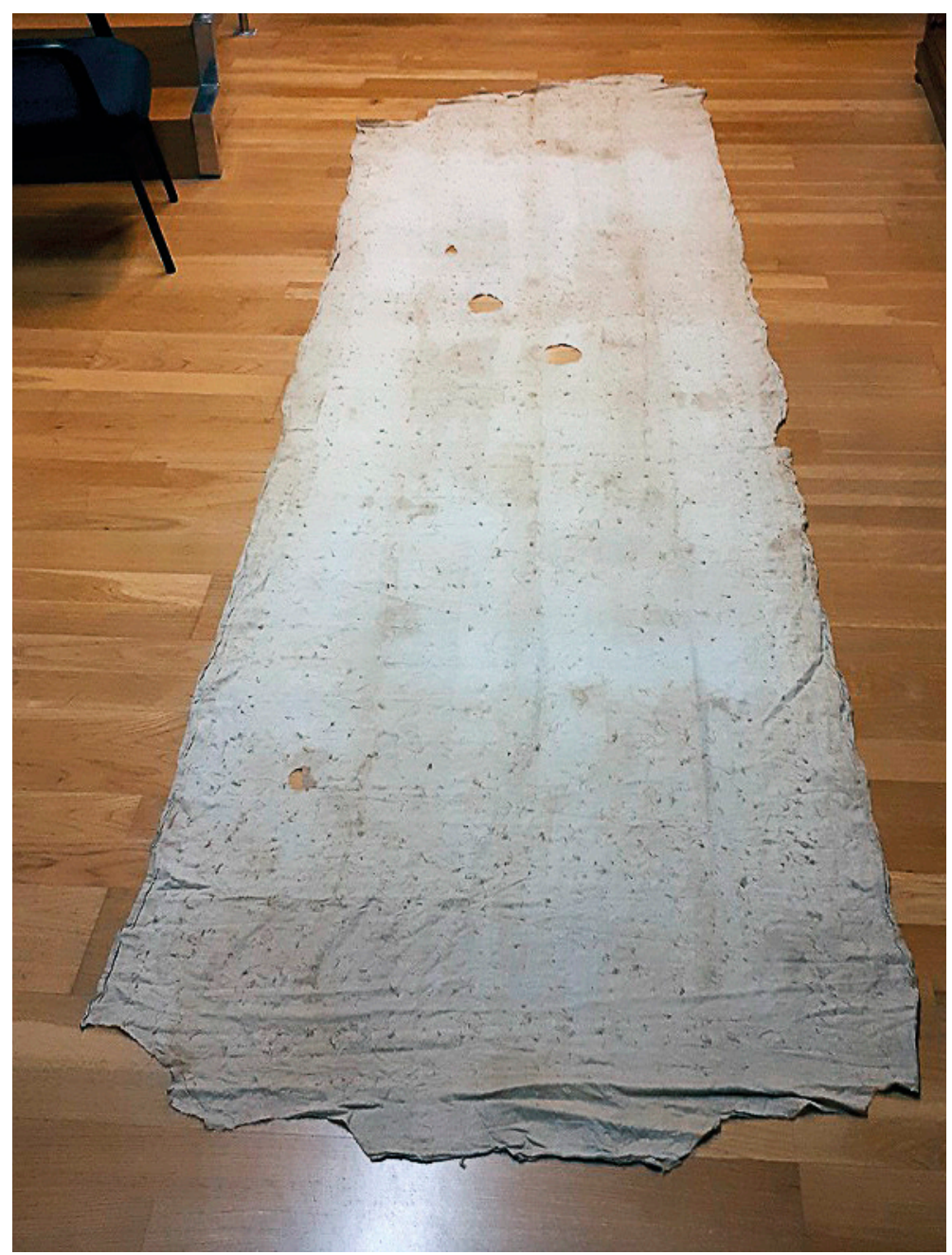

Figure 2. Sábana de Santa Eufemia. General view (photo: Mª Asunción Lavesa)

Figura 2. Sábana de Santa Eufemia. Vista general (foto: Mª Asunción Lavesa)

[...] Another big ivory box lined in taffeta and with its key. In its outline are almost full-relief figures of the history of Saint Susan. Inside this box there is a golden leather bag and inside some relics that are said to be from the crosier of Bishop Saint Eleutherius and others from his old mother in which Our Lord put the virtue that the touch of them heal those who have ailment of rabies and three pieces covered with silk and three bones discovered [...]. (Visita del obispo don Juan de Sanclemente, 1583. Archivo de la Catedral de Ourense, $\mathrm{ACO} 73 / \mathrm{r2}$ ).

These descriptions of the Sábana make it easy to identify it with the one mentioned by Ambrosio de Morales and Bishop Fernando Tricio de Arenzana and Bishop Juan de Sanclemente. It is not known whether the veil they also talk about is now lost or if it could be one of the textile fragments recovered in the Cathedral in the last few years.

Juan Muñoz de la Cueva describes the Sábana in the following terms: "[...] en los días más solemnes se saca en sus Procesiones; es de lienço delgado, labrado con primor a lo antiguo [...]” (“[...] in the most solemn days it is taken in procession; it is made of thin linen, embroidered beautifully in the old fashion [...]") (Muñoz de la Cueva, I727, Libro IV, cap. XI: I43). He admits that it cannot be known whether it was placed in the reliquary before or after the relocation of the relics in the Cathedral, and continues: "[...] El día de Santa Eufemia se toca a todos, y entre año se lleva a los enfermos cubierta 
en una bolsa de damasco, y con ella experimentan los dolientes, o el alivio, o un consuelo muy singular y notable [...]” (“[...] When Saint Euphemia's Day everybody touches it, and the days in between it is taken to the sick covered in a damask bag, and with it the sufferers experience either relief or a very singular and notable consolation [...]") (Muñoz de la Cueva, I727, Libro IV, cap. XI: I44).

As already seen, it seems that the Sábana was firstly placed in the so-called Arqueta de Santa Susana. It is an ivory casket made in the workshop of the Genovese Embriacchi and dated to the beginning of the $\mathrm{r}^{\text {th }}$ century when they were already established in Venice. As Ángel Galán y Galindo states in his study of the ivory items kept in the Cathedral Treasury, the casket arrived in 1529 from the Sacco di Roma as a donation from a certain Ramiro. Bishop Antonio Ramírez de Haro ordered the returning of the ark to Rome in $\mathrm{I}_{534}$ as Pontifical laws compel, but this could not be carried out apparently due to the lack of precedents (Galán y Galindo, 2008: 2II). Thus, the ivory chest was finally intended to keep the relics of Saint Euphemia (among them, the Sábana), one of the most sacred of all those preserved in the Cathedral. Although the depictions the ark shows correspond to the iconographic cycle of Saint Susan, the casket is known as Arqueta de Santa Eufemia ("Ark of Saint Euphemia") in the inventories (and this is how Ambrosio de Morales calls it in his description from 1572) (Florez, I765: I49; Galán y Galindo, 2008: 2II).

The Sábana was relocated at some point from this to another smaller, silver-made casket, which was presumably produced in the $18^{\text {th }}$ century - also preserved in the Cathedral Museum. As part of the decoration of this chest we can read "S Euphemia" inside an oval medallion. Therefore, it seems logical that it was customized to contain the relics of the Saint. The Sábana was found inside this second ark, and later taken out of it by the Canon Archivist Mister Miguel Ángel González — as he himself told me personally. Once it was removed and stretched, it was carefully rolled up and put into the illuminated display case where it can be admired today.

According to J. Muñoz de la Cueva, the Sábana was carried to the ill for their healing by wrapping them in it. Moreover, some mutilations can be observed on the piece, undoubtedly caused by the ill who cut up fragments of it to keep them as healing relics.

\section{Technical considerations}

\section{Technical remarks}

Location: Museum of the Cathedral of Ourense

Provenance: Reliquary of Saint Euphemia (previously in the Ark of Saint Susan). Cathedral of Ourense Treasury

Chronology: $16^{\text {th }}-18^{\text {th }}$ centuries (?)

Material: unbleached vegetal fibre (possibly flax)

Technique: plain weave for the base fabric (density: wrap: 26 threads per $\mathrm{cm}^{2}$. Weft: 21 threads per $\mathrm{cm}^{2}$ ). Embroidery in white with stem stitch, for the decoration

Dimensions: $120 \times 393 \mathrm{~cm}$

\section{Technical aspects}

The base fabric is made with a plain weave with 26 threads per $\mathrm{cm}^{2}$ in the warp and 21 in the weft. Although the weaving is quite irregular, the quality of the execution is remarkably high The fibre used is clearly vegetal, probably flax, although this must be confirmed with a chemical analysis.

The decoration is embroidered in white with a stem stitch, in the same vegetal thread as the base fabric (figure 3). The embroidery is generally well manufactured. However, there are many loose threads in the reverse of the piece, which indicates that it has not been properly concluded. No cartoons were used. Every unit of the design shows different features, and the whole composition is rather unsophisticated. It is likely that the design had been drawn on the cloth prior to the embroidery - as is the custom in these works. In any case, no remains of such drawings were found during the visual analysis.

It seems plausible that there was a previous drawing of the decorative motifs on the tissue, as it is the usual procedure in this kind of textiles. However, no trace of such drawing was found during the visual examination of the piece. At the moment we do not have any data that allows us to determine whether the embroidery was made in an embroidery hoop.

\section{Description of the Sábana}

It is an unbleached textile made of a vegetal fibre - most likely linen, but it could also be cotton; the laboratory analysis will confirm it - and shows a mottled decoration embroidered with the same unbleached thread. It seems that its original use was an altar cloth due to its large size and shape. Its measurements are $\mathrm{I} .20 \times 3.93 \mathrm{~m}$, and both selvedges are preserved, therefore we know the width of the loom used in its weaving (figure 2). 


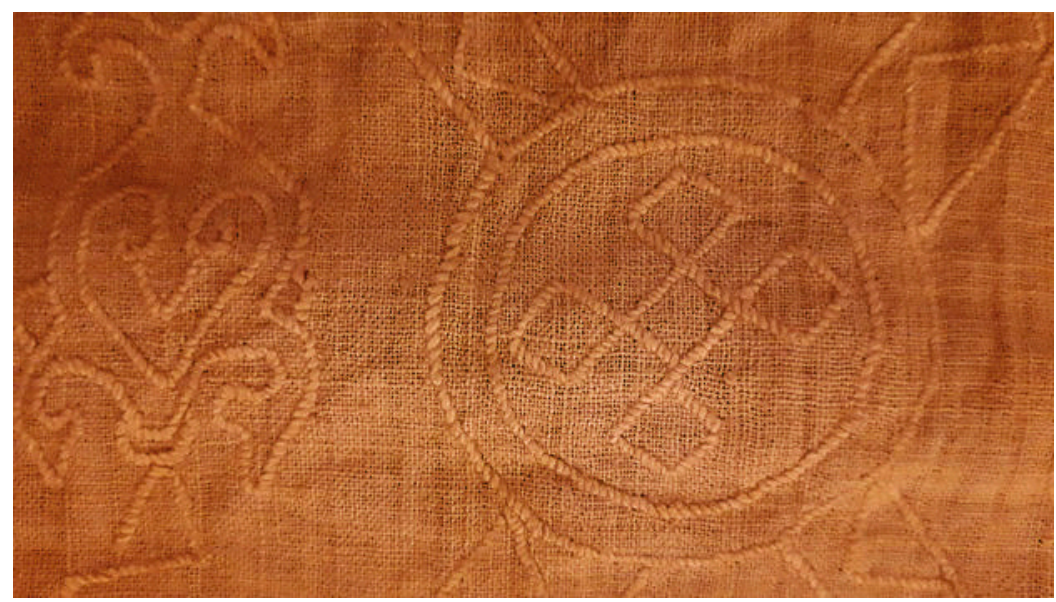

Figure 3. Sábana de Santa Eufemia. Embroidery in white. Detail (photo: Mª Asunción Lavesa)

Figura 3. Sábana de Santa Eufemia. Bordado en blanco. Detalle (foto: Mª Asunción Lavesa)

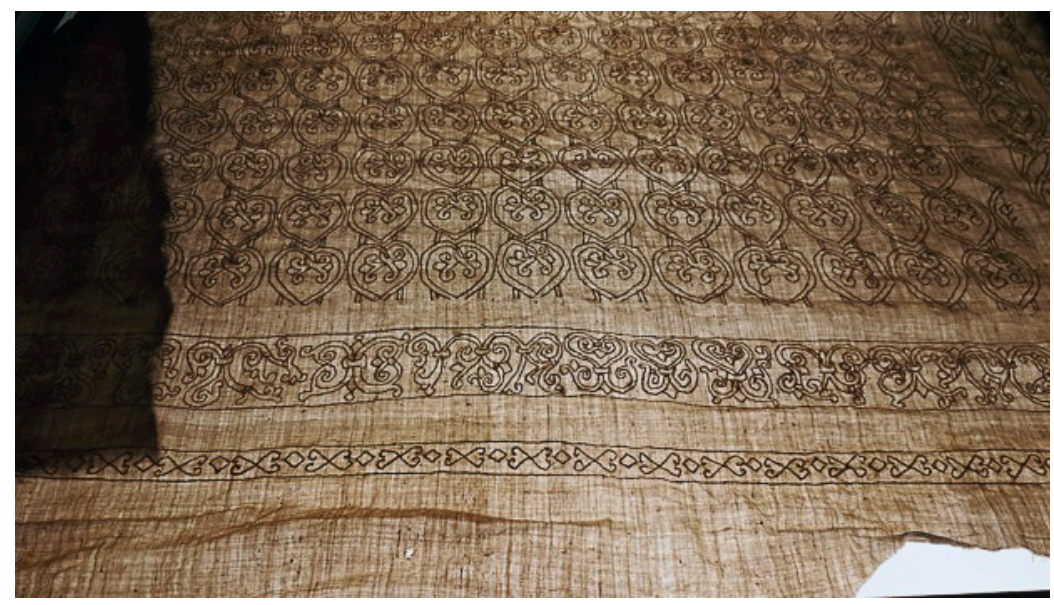

Figure 4. Sábana de Santa Eufemia. Field decorated with hearts (photo: $\mathrm{M}^{\mathrm{a}}$ Asunción Lavesa)

Figura 4. Sábana de Santa Eufemia. Campo decorado con corazones (foto: $\mathrm{M}^{\mathrm{a}}$ Asunción Lavesa)

The tissue is still in perfect condition and it is fully flexible. There are no apparent stains from the decomposition of a corpse, indicating that it has never been used as a shroud. Only a few small deposits of candle wax, and several tiny reddish stains are adhered to the fabric. These latter spots could well be blood or wine, but this must be determined by a chemical analysis in the laboratory.

The decoration is all over the fabric. It is organized in fields formed by repetitions of several motifs. The largest part of the ornamentation is placed in the central sector which borders differ each other.

A first zone of the cloth exhibits a composition with vertical bands and hearts resulted by the union of the upper part of two twigs and crowned by schematic flowers inside (figure 4). The hearth shapes make the vertical bands with two straight lists that join each other. The hearts are $6 \mathrm{~cm}$ wide and $6.40 \mathrm{~cm}$ long.

The second zone is made with the same embroidery stitch and it is formed by a web of lozenges created by a band with a zig-zag motive that joins a circular, small medallion with a double edge (figure 5). The medallion encloses a geometric figure that changes row by row. Alternative bands showing different patterns appear in the fields of lozenges. The patterns are (figure 6): a circular motif in which four triangles converge; what seems to be a passing dog (looking either to the right and to the left, depending 


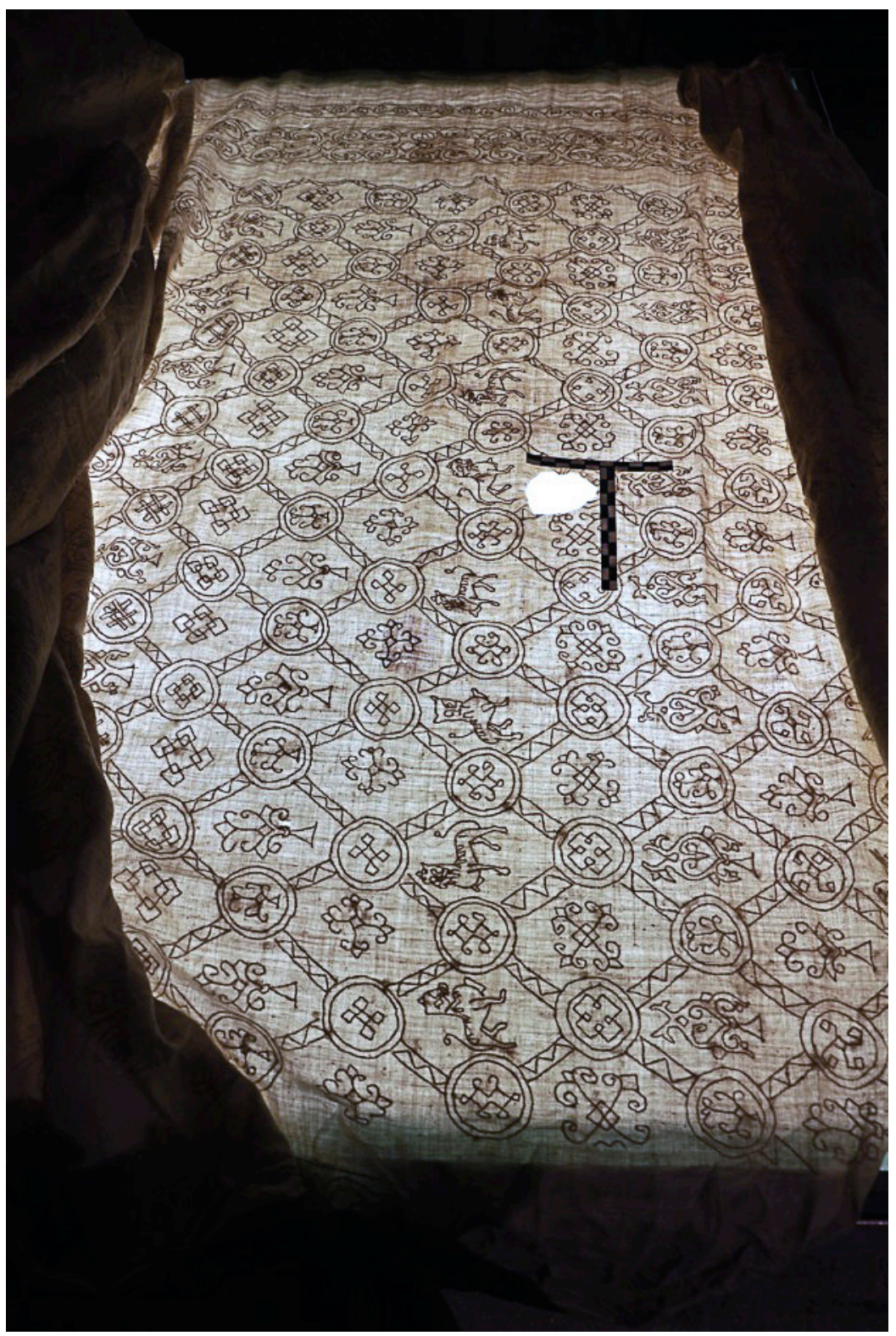

Figure 5. Sábana de Santa Eufemia. Field decorated with lozenges (photo: Iván Domínguez)

Figura 5. Sábana de Santa Eufemia. Campo decorado con rombos (foto: Iván Domínguez)

on the rhombus, so that they face each other); a stylized vegetal element with four petals; another vegetal, larger item that represents a leafy tree; a square comprised by the combination of four plain strips; the same tree once more; a cross; another vegetal item in the form of a flowered stem; another cross; a bird in profile with stretched wings; a passing feline with spots on the back; and finally a cross-shaped motif formed by branches topped with buds.

The left side of this scheme is abruptly interrupted, cutting off at least two medallions. It is as if the decoration had been produced in a loom and then cut to tailor a garment.

The union of the hearts and the ends of the bands forming the lozenges is the transition between the two ornamental compositions. Both fields are oriented in opposite directions.

As said above, the central decorative zone is framed on every side by four different sets of bands.

The horizontal end that frames the field of hearts shows a narrow strip with a series of hearts joined in their lower parts split by a diamond. It is followed by 

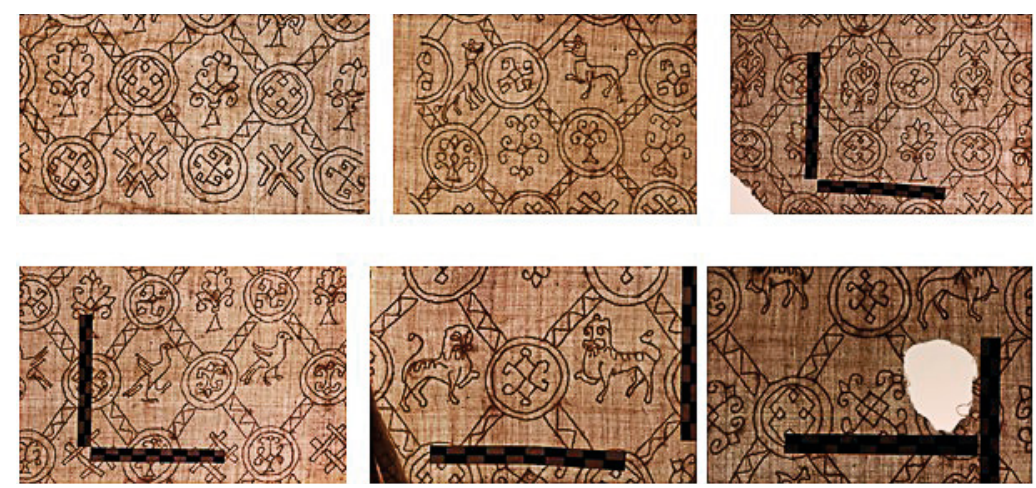

Figure 6. Sábana de Santa Eufemia. Motifs inside the rhombuses in the field decorated with lozenges (photos: Iván Domínguez)

Figura 6. Sábana de Santa Eufemia. Motivos dentro de los rombos (fotos: Iván Domínguez)

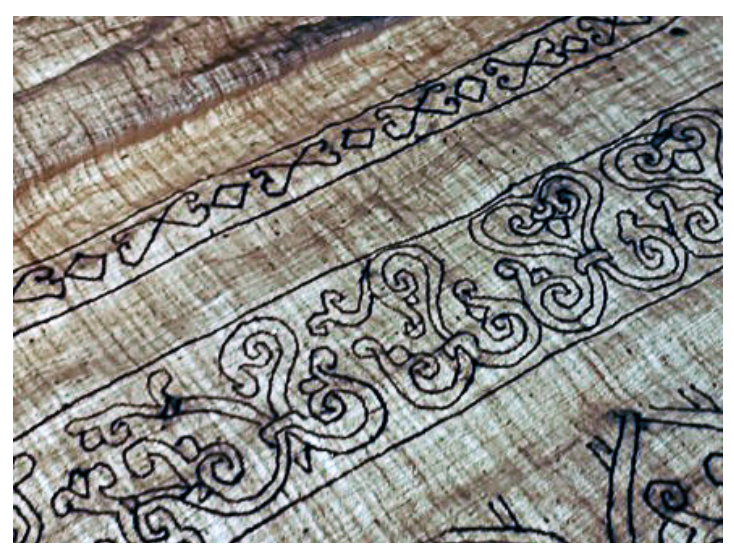

Figure 7. Sábana de Santa Eufemia. Short end framing the field of hearts (photo: Ma Asunción Lavesa)

Figura 7. Sábana de Santa Eufemia. Borde corto enmarcando el campo de corazones (foto: $M^{a}$ Asunción Lavesa)

a wider band with vegetal motifs in such a form that could be called vases. They are designed by stems emerging from a central lily that join together in the upper part by a sort of gland. They later bifurcate down to both sides in a floral stem (figure 7).

The left-hand end displays another narrow strip with a stylized rinceau. The decorative band framing the field of the hearts is ornamented with vegetal motifs more intricate than the others. It is formed by a stem from which grows another rinceau crowned with buds (figure $8 \mathrm{a}$ ).

The narrow strip in the right-hand end displays yet another continuous rinceau formed by diamond-shaped leaves divided in four parts also diamond-shaped. The wider band following this strip holds rather different motifs: they are still vegetal, but they conform hearts containing a triangular flower that reminds of Andalusi elements. The hearts are connected by the entangled stems that form them. Two branches emerge from each side (figure 8b).

Finally, the short end framing the field with lozenges shows a narrow strip with lineal decorations as interlaced rhombuses, finished in the upper and lower parts by another small ones. The band following the strip displays heart-shaped elements formed by the entwining of the branches that draw a small central heart with a triangular flower ending inside. Two more sprouts emerge from these inner stems and have triangular flower endings. All these elements certainly have a particular Andalusi taste to them. The branches are tied by a sort of heart-shaped gland and are held by another one that loops them together (figure 9).

The outer strips are $3.5 \mathrm{~cm}$ wide, and the decorative bands are $5.25 \mathrm{~cm}$ wide.

The embroidery displays a mixture of Andalusi and Renaissance motifs. This great variety of decorative features in a single piece indicates a lack of a clear iconographic program. It seems the design is nothing but different decorations put together according to the taste of the artisan, with no further intention than the sheer look.

\section{Appraisal}

I can only provide very few preliminary remarks (therefore partial) about an item still under research. As the chemical analysis is yet to be performed, final remarks are not yet available. 

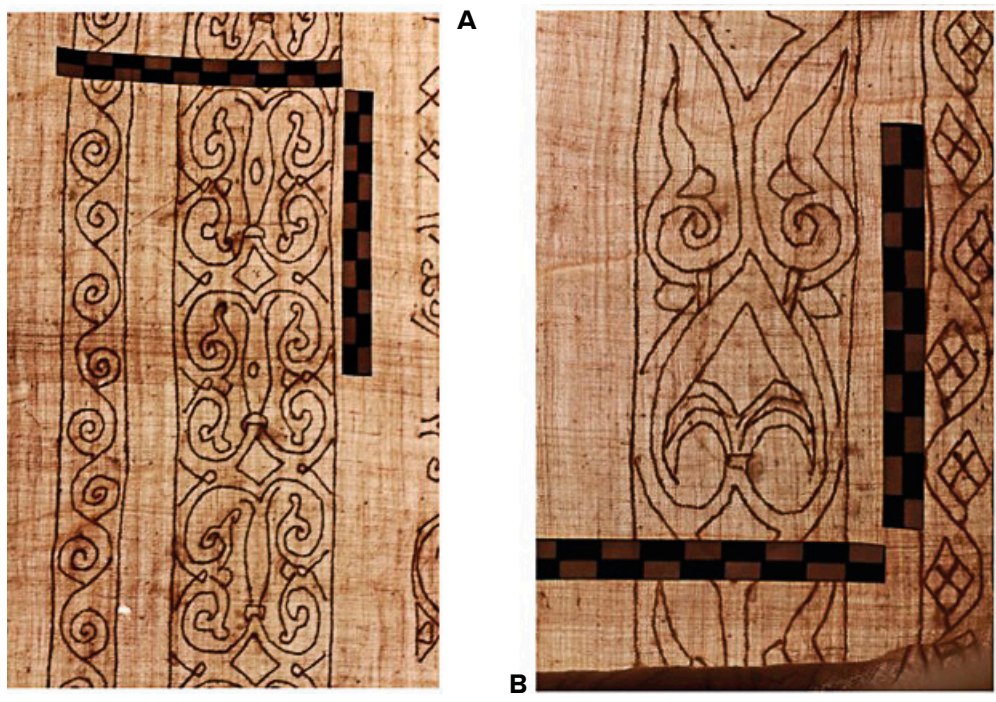

Figure 8. A. (Left): Sábana de Santa Eufemia. Long left-hand end (photo: Iván Domínguez). B. (Right): Sábana de Santa Eufemia. Long right-hand end (photo: Iván Domínguez)

Figura 8. A. (Izquierda): Sábana de Santa Eufemia. Borde largo izquierdo (foto: Iván Domínguez). B. (Derecha): Sábana de Santa Eufemia. Borde largo derecho (foto: Iván Domínguez)

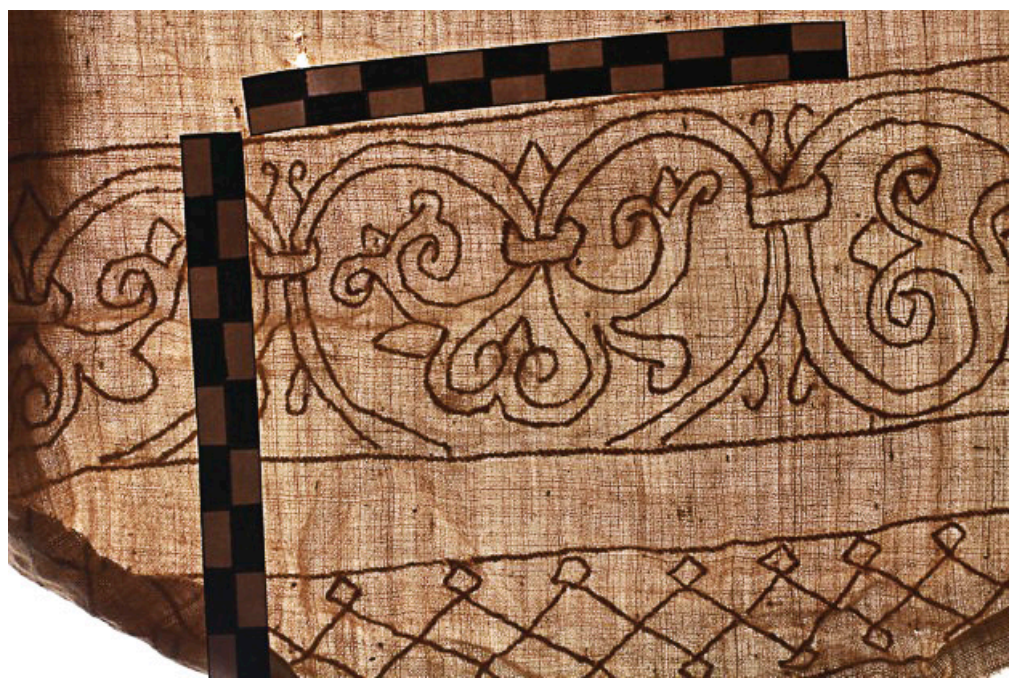

Figure 9. Sábana de Santa Eufemia. Short end framing the field of lozenges (photo: Iván Domínguez)

Figura 9. Sábana de Santa Eufemia. Borde corto enmarcando el campo de rombos (foto: Iván Domínguez)

The Sábana de Santa Eufemia is of a quite high quality, both in the plain weave of the base fabric and in the embroidered decoration. The ornamental compositions are remarkably eclectic, since they are an amalgam of elements taken from Andalusi textile art mixed with others that have clear Renaissance reminiscences.

On the one hand, some of these typical Andalusi motifs are the leaves and the triangular flowers. Also, the hearts in the main field and the general disposition of the web of lozenges with images inside. On the other hand, Renaissance motifs are the rinceau on the lateral bands.

As for the elements of Islamic origin, the hearts play an important role in this sheet. There are several parallels for them in Andalusi textile art, metal, ivory, stone, and architectural decorative panels. For instance, there are similar forms among the parietal ornamentations found in Madīnat al-Zahrä' 
(Cordova, Andalusia, Spain), and in the ivory pieces made in the official workshops from the Caliphate of Cordova.

The inner ending of the elements placed in one of the frames is also small, heart-shaped, topped with a triangular shape of Cordovan origin: They are stylized leaves and fruits, often used in Andalusi art. We find them on textile in very early pieces, such as a reliquary bag from the Cathedral of León, or on the tapestry strips from the infulae of Saint Valerius's mitre, from the Cathedral of Roda de Isábena (Huesca, Aragón, Spain). We see similar forms in architectural decoration such as on a base of a column, probably from Madinat al-Zahrā', preserved in the Archaeological Museum of Seville (inv. no. CEooo57).

The vegetal figures on another band of the Sábana are similar to those on some Andalusi silks from the Ioth and IIth centuries, like the so-called Franja del Pirineo - probably from the Cathedral of Roda de Isábena (Huesca, Aragón, Spain) as well — kept in the Instituto Valencia de Don Juan in Madrid (inv. no. 207I).

The animals on the lozenges, clumsy as they are, show reminiscences of some Andalusi items. This is clear on the felines with spots on the back that look remarkably alike to, for instance, a fountain spout preserved in the Archaeological Museum of Seville (inv. no. $\mathrm{REP}_{22392}$ ), dated to the $\mathrm{II}^{\text {th }}$ century.

The birds with semi-stretched wings parallel some textiles from the irth and I2th centuries, such as a fragment from the tapestry trimming of the alb of Arnaldo Ramón de Biure, abbot of the Monastery of Sant Cugat del Vallés (Barcelona) between 1348 and 1350 .

Moreover, the general composition, both of the web of lozenges and of the field of hearts, powerfully reminds of some Andalusi tissues. The lozenge pattern, especially, seems directly inspired by some silk items evolved from of the merely Almoravid textiles, such as a fragment now in the Victoria and Albert Museum in London (inv. no. 275-1894). However, the quality of the manufacture together with the design detail are much higher in the London silk. In the Ourense piece, there is a simple zig-zag line instead of the Kufic inscriptions framing the rhombuses in the London one. Also, the pairs of griffons and peacocks of the London silk become a single figure in each diamond-shaped medallion, switching animal forms with vegetal and geometric forms in the Ourense one.

Not all the elements depicted in this embroidery are of Andalusi origin; some are not even medieval at all.

To begin with, the dogs in some of the rhombuses can hardly be considered Islamic. Since there are numerous references to the impurity of the dog in canonical sources, it seems unlikely that an image of it would be included in a textile. In fact, Islam forbids the possession of dogs, except if they are used in hunting or shepherding. For instance, in a hadith dated to I490,

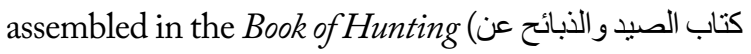
- that is part of the compilation of hadiths Ŷāmi' al-Tirmidìi (جامع الترمذي) by Iman Abū 'Isa Muhammad al-Tirmid̄i — Abū Huraīra said: "Whoever keeps a (pet) dog which is neither a watch dog nor a hunting dog, will get a daily deduc-

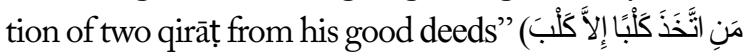

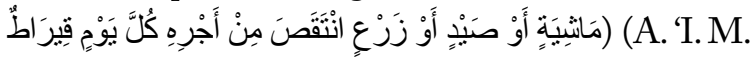
al-Tirmidīi, I49o, Book I8, hadith 32, I7).

There are geometric and vegetal elements that, although have a clear Islamic origin, seem a later interpretation of typical medieval motifs. The embroiderer seems to have been inspired by Andalusi works of art with arabesques to create their own version of the theme, with a Renaissance kind of touch in some of the bands around the central field. It is reminiscent of grotesques, typical in European architectural decoration in the i6th century.

Due to this combination of elements taken from different traditions in a single fabric, I do not consider it feasible to date the cloth before the $\mathrm{I}^{6^{\text {th }}}$ century. This post quem date is provided too by the references to the textile by Ambrosio de Morales and the two Bishopric visits from the same century, which describe the textile as "labrada de buena labor blanca" ("embroidered in a good white labour"). So far, these would be the oldest mentions to the piece I have found. However, only after the laboratory analysis is performed can an accurate chronology be confirmed.

Moreover, the piece is exceptionally well preserved: the fabric is completely flexible, and it presents a few small tears, apart from the cuts intentionally made to provide the sick with relics. There are no 
stains due to cadaverous decomposition either, thus the well-preservation is logical since it has never been in contact with a corpse.

The manufacture of the embroidery, although quite good, has some characteristics that lead to think that it is not a professional work: it is not well finished on the back side, where there are many loose threads. In addition to this, all the motifs are different from each other and a bit unsophisticated, so it is likely that the embroiderer did not use a template to make them. It appears that the artisan copied - or rather interpreted - a previous textile model. This model could have been an older Sábana attributed to Saint Euphemia, which would have deteriorated after having long flowed among the sick in the city. Hence, I believe this is a personal interpretation by someone who has certainly seen medieval textiles (probably from al-Andalus). These tissues may have belonged to the Cathedral Treasury. The embroiderer combined some of the motifs that appeared on those hypothetical textiles on a single cloth. Perhaps by doing this they tried to "sanctify" their work as much as possible. ${ }^{4}$ In this way, he has deprived elements full of symbolism of their meaning by not following an iconographic program when placing them on the fabric. The result is an array of images with an undoubtedly medieval taste, but also exhibiting some more evolved features, never connected to one another.

Alas, this interpretation cannot be confirmed archaeologically so far: no remains of this hypothetical first Sábana have been discovered, neither written records been found of the moment when it could have been replaced by the one we can admire today.

In fact, while waiting for the laboratory analyses, it can be stated that this fabric may well have been made after the I6th century, possibly in I70o's, copying

4 Almost all the motifs displayed on medieval Islamic textiles were symbols of power. In Christian contexts they acquire an additional meaning as the representation of the victory of Christians over Muslims. This is why Andalusi textiles were used as wrappings for relics: they highlighted the holiness by the appropriation of the image of Muslim power in the most sacred spots of the Christian cult. In this case, by combining all these motifs the artisan tried to place all these symbols of power on a single textile, so it became even more sacred. In fact, this embroidery is almost as a catalogue of symbols, so to speak. an older one. This may be connected to the moving of the relics to the silver ark in which they were found.

Another reason for a post-medieval dating is the fact that the artistic embroidery in white appears in the $16^{\text {th }}$ century. Before that all embroideries were made only with colour threads (González Mena, 1974: 83). Furthermore, this piece is an example of popular embroidery. This kind of needlework shows a clear stagnation in the patterns, the techniques, and even the materials used - hence it is not an oddity to make an array from different elements.

This Sábana de Santa Eufemia is in fact a "cloth of honour", placed in the reliquary to enhance or protect the relics, and eventually becoming a venerated secondary relic since it is in touch with the holy body.

Although, at first sight, it may seem paradoxical, the textiles used as wrappings for the most sacred relics in Christian churches in the Middle Ages usually come from al-Andalus or the Islamic East. This does not happen exclusively in Iberia, although it acquires a somewhat different significance in the Spanish Neo-gothic principalities, giving the presence of al-Andalus, chiefly an Oriental society in the West. Only by understanding the relationship between the different polities in the Iberian Peninsula one can understand the reason behind the use of objects of prestige manufactured by the enemy as elements of the cult.

All medieval luxury goods, Andalusi and otherwise, bare images with a high symbolic substance, normally allusive to the funerary world and to power. The meanings of all these motifs shift in the passing from Islam to the Christian world. At the same time, these items gain an additional connotation as spolia - representing victory, both warlike and moral, of Christianism over Islam. ${ }^{5}$ Besides, the sheer fact of being expensive items native to exotic countries (often as war prize) grants them a bonus which accounts for why they are automatically adopted as symbols of the holy in their new locations.

5 Spolium (pl. spolia): from Latin, meaning "spoil" as in "spoil of war"), booty or loot. In this case, it is the reuse of elements from the defeated enemy in the most significant spaces of the conqueror. 
The sacral sense of the Sábana is linked to the healing powers they are attributed to it, since it was taken to the sick who even cut out fragments of it to keep them as heling amulets. The decorative motifs on the textile are fully symbolic in the medieval world, Islamic as well as Christian, even when they appear in an isolated and disjointed way with no apparent iconographic

\section{Bibliography $^{6}$}

al-Tirmidīi, A. 'I. M. (I490): Ŷāmi' al-Tirmid̄ī, Book of Hunting, Book I8, Hadith 32, I7.

Carrero Santamaría, E. (2004): "Paraliturgia, ajuar hagiográfico y lugares de enterramiento en torno a los obispos santos de Galicia y de León entre los siglos IX y xI". Porta da Aira: Revista de historia del arte orensano, Iо: 8-54.

Cid, Orense, J.R. (2017): Catedral, Museo. Sábana de Santa Eufemia, fragmento, (s. XII?), online, https://www.flickr.com/photos/88068852@No5/ 23705181091

Estrella Marcos, M.M. (2012): La escultura de marfil en España: románica y gótica. Valladolid.

Florez, H. (1765): Viage de Ambrosio de Morales por orden del rey D. Phelipe II a los reynos de Leon, y Galicia, y Principado de Asturias, para reconocer las reliquias de Santos, Sepulcros Reales, y Libros manuscritos de las Cathedrales, y Monasterios. Dale à luz con notas, con la vida del autor, y con su retrato, El Rmo. P. Mr. Fr. Henrique Florez, del Orden del Gran Padre S. Agustin. Madrid. program, as it would be logical in this sort of textiles. In short, it is an interesting case of the continuity on the usage of Oriental patterns in sacred objects. It could be said that this embroidery proves al-Andalus influences in the Neo-gothic principalities persist beyond its very existence, surviving in the practice of stressing the holiness of the relics with Oriental elements.

Galán y Galindo, A. (2008): "Los marfiles del museo de la catedral de Ourense”. Porta da Aira: Revista de historia del arte orensano, I2: 18I-220.

González Mena, M.A. (1974): Instituto Valencia de Don Juan. Catálogo de bordados. Madrid.

Hernández Figueiredo, J.R. (2016): Aportaciones a la memoria histórica de Santa Eufemia de Ourense. Ourense.

López Morais, A. (199I): "Orense en las grandes exposiciones de arte”. Porta da Aira: Revista de historia del arte orensano, 4: 249-267.

Muñoz de la Cueva,J. (I727): Noticias históricas de la santa Iglesia Cathedral de Orense. Madrid.

Otero Pedrayo, R. (1954): Guía de Galicia. Vigo.

Rodríguez González, A. (2013): Santa Eufemia, Pieza del Mes, Museo Arqueolóxico Provincial de Ourense, enero $20 I_{3}$, online, http://www.musarqourense. xunta.es/wp-content/files_mf/pm_20I3_or_espi3. pdf

Sánchez Arteaga, M. (1916): Apuntes histórico-artísticos de la catedral de Orense. Ourense.
6 For a broader bibliography on historical textiles and on research methodology, see my $\mathrm{PhD}$ dissertation Aproximación arqueológica a los tejidos andalusies (https://repositorio.uam.es/ handle/I0486/687847). 